Jeff Brink

Stephen J. Meraw

David P. Sarment

\title{
Influence of implant diameter on surrounding bone
}

Key words: animal study, bone/implant contact, dental implants, implant diameter, osseointegration

Authors' affiliations:
Jeff Brink, Department of General Dentistry, University of Michigan Dental School, Ann Arbor, MI, USA

Stephen J. Meraw, David P. Sarment, Department of Periodontics and Oral Medicine, University of Michigan Dental School, Ann Arbor, MI, USA David P. Sarment, Center for Biorestoration of Oral Health, University of Michigan Dental School, Ann Arbor, MI, USA

\section{Correspondence to:}

Dr David P. Sarment

Department of Periodontics and Oral Medicine

University of Michigan Dental School

IoI I North University Avenue

Ann Arbor, MI 48I09-1078

USA

Tel.: 7347632 IO5

Fax.: 7347635503

e-mail: sarment@umich.edu
Date:

Accepted 30 January 2006

To cite this article:

Brink J, Meraw SJ, Sarment DP. Influence of implant

diameter on surrounding bone.

Clin. Oral Impl. Res. I8, 2007; 563- 568

doi: I0.I I I I/j.I600-050I.2007.0I $283 . X$

\begin{abstract}
Objectives: Implant osseointegration is dependent upon various factors, such as bone quality and type of implant surface. It is also subject to adaptation in response to changes in bone metabolism or transmission of masticatory forces. Understanding of long-term physiologic adjustment is critical to prevention of potential loss of osseointegration, especially because excessive occlusal forces lead to failure. To address this issue, widediameter implants were introduced in part with the hope that greater total implant surface would offer mechanical resistance. Yet, there is little evidence that variation in diameter translates into a different bone response in the implant vicinity. Therefore, this study aimed at comparing the impact of implant diameter on surrounding bone.

Material and methods: Twenty standard $(3.75 \mathrm{~mm})$ and 20 wide $(5 \mathrm{~mm})$ implants were placed using an animal model. Histomorphometry was performed to establish initial bone density (IBD), bone to implant contact (BIC) and adjacent bone density (ABD).

Results: BIC was $71 \%$ and $73 \%$, whereas $A B D$ was $65 \%$ and $52 \%$, for standard and wide implants, respectively. These differences were not statistically different $(P>0.05)$.

Correlation with IBD was then investigated. BIC was not correlated with IBD. ABD was not correlated to IBD for standard implants $\left(r^{2}=0.126\right)$, but it was correlated with wide implants $\left(r^{2}=0.82\right)$. In addition, a 1:1 ratio between IBD and ABD was found for wide implants. It can be concluded, within the limits of this study, that ABD may be influenced by implant diameter, perhaps due to differences in force dissipation.
\end{abstract}

Osseointegration is a well-documented consequence of implant placement (Albrektsson et al. I988). Yet, there continue to be failures that occur early after surgery, or later in the life of the prosthesis. After an implant is inserted, the initial healing involves bone remodeling in its vicinity, resembling the repair of a fractured bone. To avoid excessive stress to the osseous tissue and maximize the chances of success, research has suggested long healing periods before exposure and loading in order to obtain sufficient bone/implant contact (BIC) (Johansson \& Albrektsson I987; Albrektsson \& Sennerby I990) and adequate resistance to forces when implants first undergo loading. Later, bone continues to mature and adapt while occlusal forces are occurring.

Factors influencing the amount of BIC have been investigated, using animal models. They include the original bone density (Cho et al. 2004), the amount of forces applied to the implant through function (De Pauw et al. 2002), the implant material and shape (Carr et al. 2000), the surface 
roughness (Trisi et al. 2003), as well as the implant length and width (Ivanoff et al. 1997).

The distribution of stress toward surrounding bone is thought to be critical for long-term maintenance of the initial osseointegration, and bone remodeling in response to load has been studied. When excessive forces are applied, such as in the animal experiment described by Isidor (1996), osseointegration may be lost. Gotfredsen et al. (200Ia), using an animal model to compare loaded and non-loaded implants, reported that increased bone contact and adjacent density occurred with constant lateral forces. Duyck et al. (200I) compared lateral continuous vs. dynamic loading on implants placed in a small animal. They found that dynamic loading was correlated with less bone density in the vicinity of the implant, although BIC was not affected. Gotfredsen et al. (200Ib) utilized a constant lateral loading force on an animal model, and found that implant surface treatment impacted bone density and BIC. However, under identical conditions, bone density or BIC was not different when forces were applied for a longer period, suggesting that these parameters were stabilized after a few weeks. Using finite element analysis (FEA), reports have shown that occlusal stress is distributed via the implant, and differences exist with regard to stress distribution and implant shape. Holmgren et al. (I998), using two-dimensional FEA, suggested that implant diameter and shape play a role in stress distribution. Later, Himmlova et al. (2004) also found that diameter has more influence than length in stress distribution. Interestingly, although implant shape and thread design have been modified over time to accommodate for better spreading of load, little histological evidence has supported these claims.

One of the factors influencing stress distribution is implant diameter. Largediameter implants were first introduced to expand implant placement in areas of poor bone density and limited availability of height. One suggested advantage is that, for the same length, a wider implant presents a greater total surface, as supported by subsequent research (Ivanoff et al. I997). Consequently, the total BIC may be greater, compensating for the lack of height or bone density. However, wider

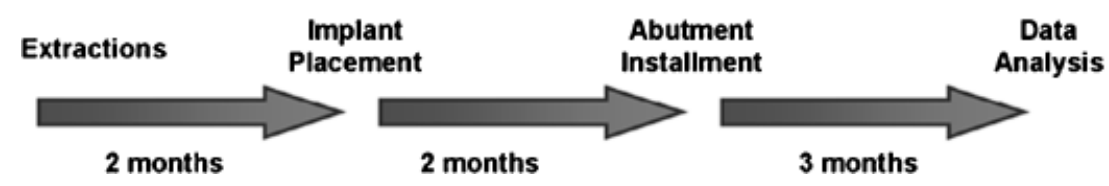

Fig. I. Study timeline.

implants are utilized where bone is scarce and the influence of diameter on BIC may not translate into a clinical advantage (Ivanoff et al. 1999). Therefore, this study aimed at determining the influence of implant diameter on BIC and surrounding bone density.

\section{Materials and methods}

Five adult male mongrel dogs received 20 standard diameter and 20 wide implants in this prospective randomized experimental study (Fig. r).

\section{Surgeries}

Animal care throughout the study was performed by the Veterinary Sciences Department at the University of Michigan. For all surgeries, dogs were administered $20 \mathrm{mg} / \mathrm{kg}$ intravenous $4 \%$ thiamylan sodium (Surital ${ }^{\mathbb{B}}$; Park Davis Co., Detroit, MI, USA) as general anesthesia. Surgical sites were disinfected and anesthetized using $2 \%$ lidocaine HCL with I : I00,000 epinephrine. Following surgery, they were administered intramuscular butorphanol and penicillin (Flo-Cillin ${ }^{18}$; Fort Dodge Laboratories Inc., Fort Dodge, IA, USA).

The first surgery consisted of atraumatic extractions of all second, third and fourth premolar and first molar teeth. Releasing incisions were placed to obtain primary closure, followed by suturing with 4-O polyglactin 910 suture (Vicryl ${ }^{\mathrm{w}}$; Ethicon Inc., Johnson\&Johnson Co., Sommerville, NI, USA). Extraction sites were allowed to heal for 2 months before the next surgery.

The second surgery consisted of implant placement (Fig. 2). Full-thickness mucoperiosteal flaps were reflected on the facial and lingual sides for ridge visualization. Implant surgical sites were prepared in the standard fashion, measuring at least Io $\mathrm{mm}$ between centers of the osteotomies. Dental implants were surgically placed in a random order with sterile water cooling. One standard-diameter implant and one wide-diameter implant $3.75 \times 5 \mathrm{~mm}$ and

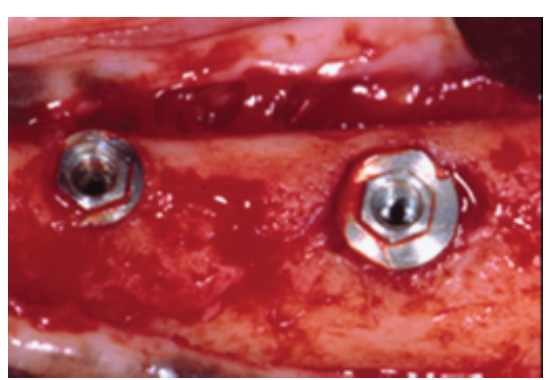

Fig. 2. Surgical site at the time of implant placement. Implants were positioned with sufficient distance to allow for histologic evaluation of adjacent and distant bone.

$5 \times 5 \mathrm{~mm}$; Implant Innovations, Palm Beach Gardens, FL, USA) were placed in each quadrant in a randomized order. Cover screws were secured and surgical flaps were reapproximated and closed with 4-O polyglactin 910 suture.

After 2 months, implant exposure was performed. Full-thickness mucoperiosteal flaps were incised as described previously to gain access to implants. Cover screws were removed and healing abutments were selected and tightened to the implants. Surgical flaps were positioned and sutured. After healing, a hygiene regimen was instituted for the remaining 3 months. Investigators inspected implants weekly to insure that the sites remained free of clinical inflammation.

Histology and histomorphometric analysis The subjects were euthanized and jaw specimens were retrieved so that at least $10 \mathrm{~mm}$ of osseous was left intact on the mesial and distal sides of implants. Samples were fixed in $70 \%$ ethanol, dehydrated with successive alcohol and GMA (2-hydroxyethylmethacrylate) concentrations. Plastic infiltration of specimens was accomplished with an even mixture of GMA and embedding medium (Technovit 7200 VLC $^{\mathbb{B}}$, Kulzer: EXAKT, Kulzer \& Co., Norderstedt, Germany), followed by repeated immersions in $100 \%$ embedding medium. Specimens were later sectioned with the use of a micro-grinding system until a final 

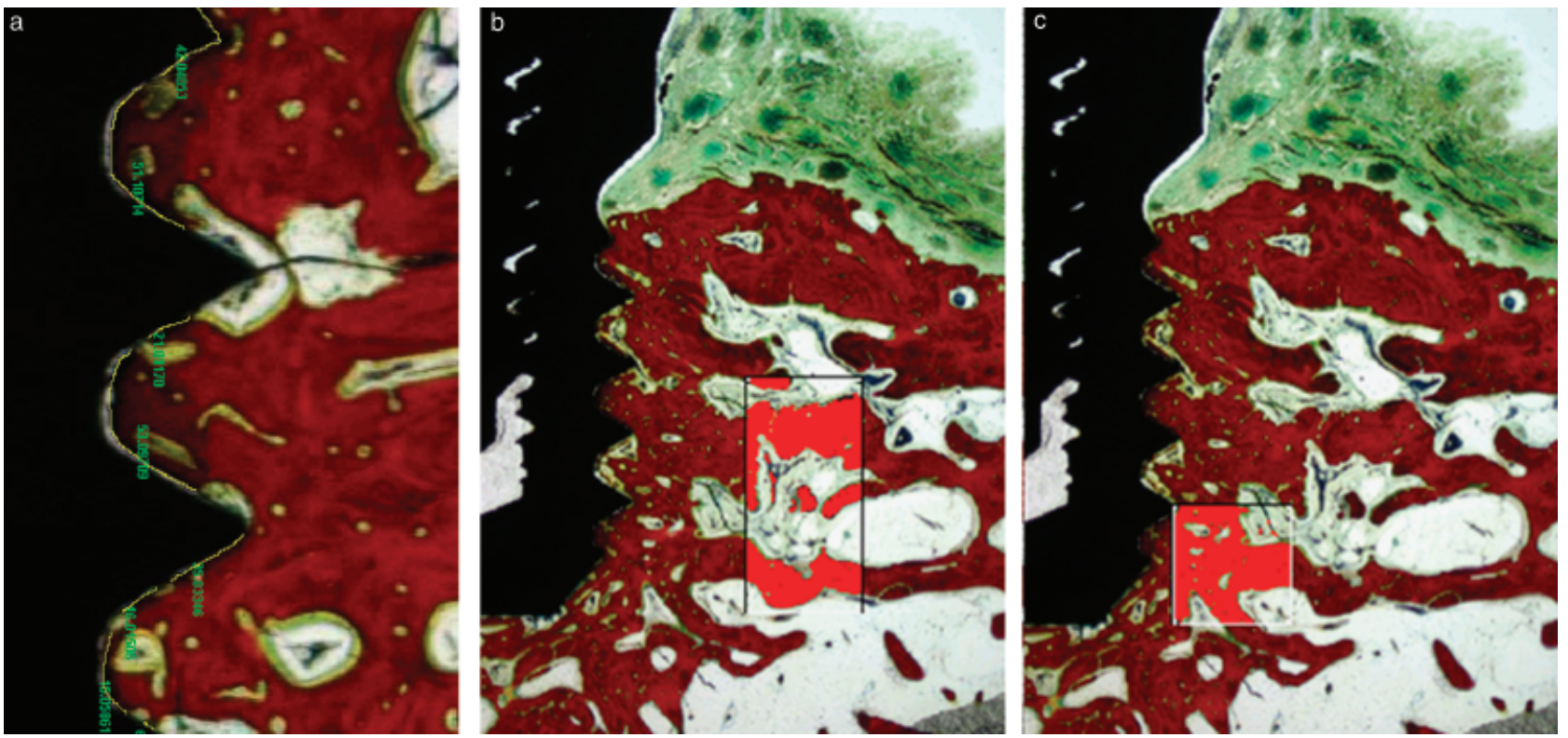

Fig. 3. Histomorphometric measurements were comprised of (a) bone to implant contact, (b) initial bone density and (c) adjacent bone density.

thickness of $<50 \mu \mathrm{m}$ was obtained (Rohrer \& Schubert I992).

Histologic specimens were analyzed under $\times$ Ioo magnification with the use of a semi-automated computerized technique at a Leitz Orthoplan microscope (Leica Microsystems Inc., Bannockburn, IL, USA), interfaced with an IBM computer and a Bioquant HIPAD digitizer (Bioquant Corp., Nashville, TN, USA).

Histomorphometric measurements (Image-Pro Plus, Media Cybernetics, Silver Spring, MD, USA) included BIC (a linear measurement along the axial wall of the sectioned implant); initial bone density (IBD; the density of bone occupied in a defined area of interest at least $3 \mathrm{~mm}$ away from the implant); and adjacent bone density (ABD;

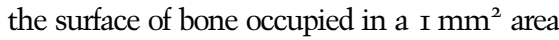
of interest in contact with the apical portion of the axial wall of the implant) (Fig. 3).

Paired $t$-tests were utilized to compare IBD, ABD and BIC for standard and wide implants. A regression coefficient was calculated when exploring the influence of IBD on ABD and BIC.

\section{Results}

Forty implants were placed. Two implants were lost at the time of exposure because of lack of osseointegration. IBD varied from $7 \%$ to $68 \%$, with an average of $39 \%$ ( $\mathrm{SD}=\mathrm{I} 5 \%$ ). For standard implants, it var-
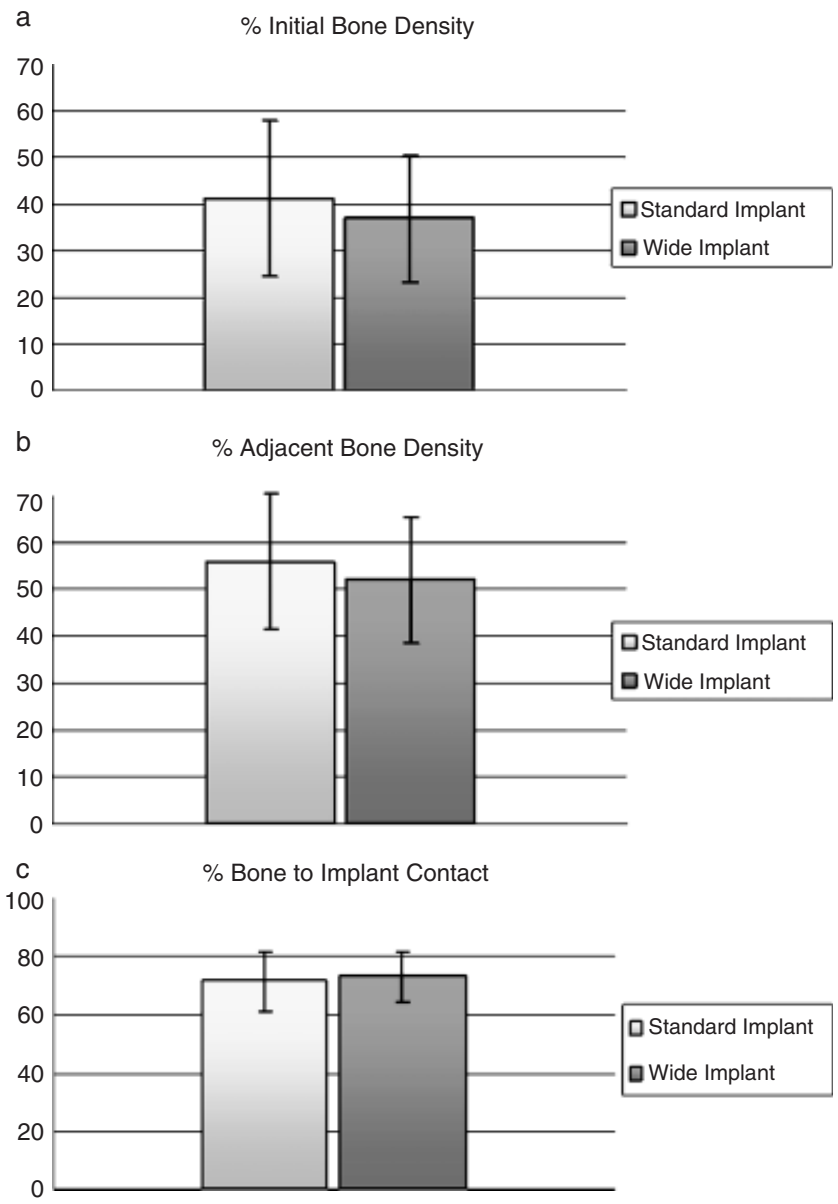

Fig. 4. Percentage of initial bone density, adjacent bone density and bone to implant contact for standard and wide implants (average $\pm \mathrm{SD}$ ).

ied from $13 \%$ to $68 \%$, with an average of $4 \mathrm{I} \%(\mathrm{SD}=\mathrm{I} 6 \%)$. For wide implants, IBD varied from $8 \%$ to $60 \%$, with an average of
$37 \%(\mathrm{SD}=\mathrm{I} 4 \%)$. The difference between implant diameters was not statistically significant $(P>0.5)$ (Fig. 4a). 

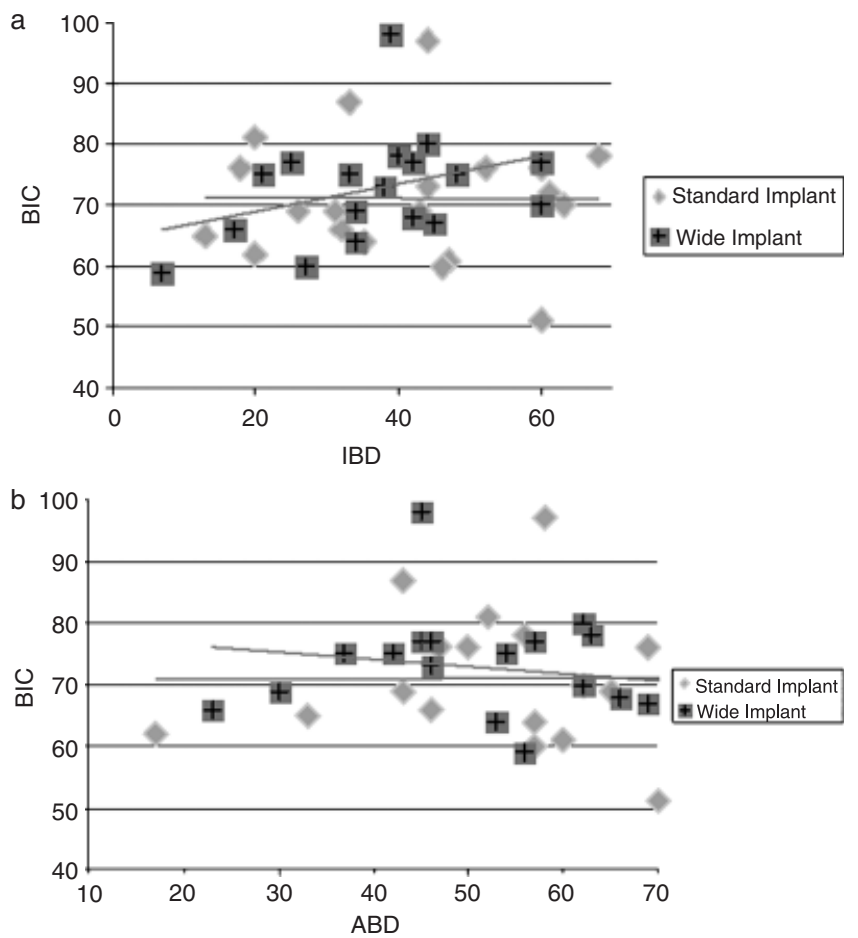

Fig. 5. Influence of various parameters on percentage bone to implant contact (BIC). (a) BIC was not influenced by the initial bone density $\left(r^{2}=0.36\right.$ for standard implants, and $r^{2}=-0.0$ I for wide implants $)$ (b) when investigating the influence of adjacent bone density (ABD) on BIC, there was no correlation between standard and wide implants as well $\left(r^{2}=0.005\right.$ for standard implants, and $r^{2}=-0.2$ for wide implants $)$.

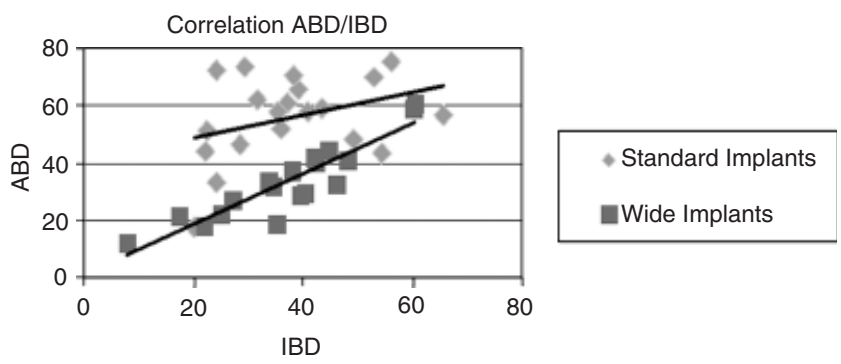

Fig. 6. Correlation between initial bone density (IBD) and adjacent bone density (ABD). For standard implants, correlation was poor $\left(r^{2}=0.13\right)$ but ABD was greater than IBD. For wide implants, a significant correlation existed $\left(r^{2}=0.82\right.$ with a I : I ratio $)$.

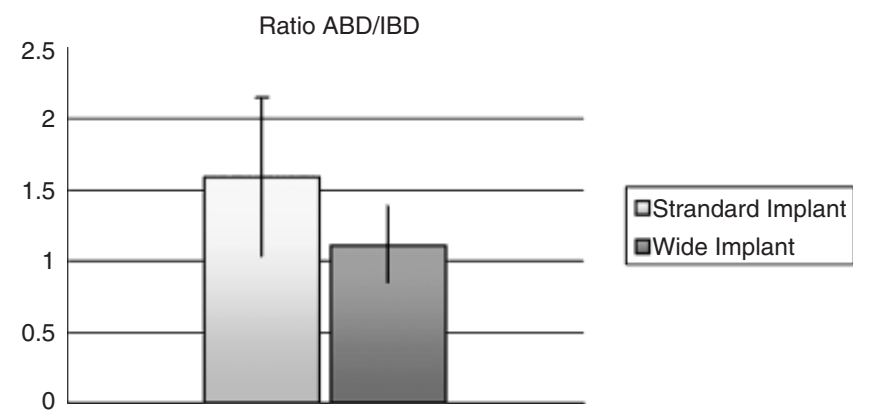

Fig. 7. A ratio of adjacent bone density (ABD) to initial bone density (IBD) highlights differences between groups. ABD/IBD was I.6 $\pm 0.56 \mathrm{SD}$ and I.I $2 \pm 0.26 \mathrm{SD}$ for standard and wide implants, respectively.

ABD for standard and wide implants was $54 \%(\mathrm{SD}=\mathrm{I} 4 \%)$ on average. For standard implants, $\mathrm{ABD}$ varied from $18 \%$ to $75 \%$, with an average of $56 \%(\mathrm{SD}=\mathrm{I} 4 \%)$. For wide implants, $\mathrm{ABD}$ varied from $23 \%$ to $72 \%$, with an average of $52 \%(\mathrm{SD}=\mathrm{I} 3 \%)$.
This difference between groups was not statistically significant $(P>0.5)$ (Fig. $4 \mathrm{~b})$.

With regard to $\mathrm{BIC}$, the results varied from $51 \%$ to $97 \%$, with an average of $71 \%$ (SD $=\mathrm{IO} \%$ ) for standard implants, and from $60 \%$ to $93 \%$, with an average of $73 \%(\mathrm{SD}=8 \%)$ for wide implants. Again, these results were not statistically significant $(P>0.56)$ (Fig. 4c).

Correlations between IBD, BIC and ABD were then investigated. For BIC, there was no correlation to the IBD, although a slight relationship could be noted for standard implants only (standard implants, $r^{2}=0.36$ and wide diameter implants, $r^{2}=-$ o.oI) (Fig. 5a). Similarly, BIC was not correlated to the ABD, although a slight decreasing trend could be noticed for standard implants $\mid r^{2}=0.005$ for standard implants and $r^{2}=-$ O.I 8 for wide implants) (Fig. 5b). However, for ABD, the findings were noteworthy: a significant correlation was found for wide-diameter implants $\left(r^{2}=0.126\right.$ vs. 0.82 , respectively). Figure 6 represents ABD's correlation to IBD for both groups, also underscoring a I : I correlation for wide implants. Finally, a ratio of $\mathrm{ABD}$ to $\mathrm{IBD}$ was calculated: it was I.6 ( $\pm 0.56 \mathrm{SD})$ for standard implants and I.I2 ( $\pm 0.26 \mathrm{SD})$ for wide implants (Fig. 7).

\section{Discussion}

Implant failure rate varies with the type of prosthesis, and is reported to range between $3 \%$ and $22 \%$ (Goodacre et al. 2003). Application of excessive forces is thought to be a cause for failure, and understanding of peri-implant physiology is critical.

To address these issues and provide greater implant surface, in particular in areas of the mouth where bone quantity and density are compromised, wide-diameter implants were introduced. Yet, there has been limited histological evidence that increased surface provided by wider implants has an impact on surrounding bone. Ivanoff et al. (I997), using a rabbit model, suggested that greater bone support is provided with wider implants. However, they also reported in a subsequent retrospective clinical study that wider implants had demonstrated a lower success rate (Ivanoff et al. I999). These findings demonstrate that better understanding of im- 
plant diameter on percentage BIC as well as influence on surrounding adjacent bone is necessary. This study revealed significant differences in $\mathrm{ABD}$ in standard vs. wide implants: bone density was not affected by the presence of wide implants, whereas it was increased with standard implants. This is in agreement with FEA studies. Using two-dimensional FEA, Holmgren et al. (I998) found that implant diameter was critical to stress distribution. Using threedimensional FEA and comparing the influence of implant diameter or length on surrounding coronal bone, Himmlova et al. (2004) reported that diameter played a significant role, whereas length did not. Although they only analyzed localized stress, a reduction of more than $47 \%$ was found between narrow and wide implants. Finally, supporting evidence is found in other FEA research comparing loading and nonloading conditions (Papavasiliou et al. I996; Holmes \& Loftus I997). These studies also reported that stress mostly occurred at the marginal area. In the present study, such localization was not possible to reproduce. One explanation may be that implants were relatively short; another is that physiologic forces only were applied. Excessive localized forces may not have histological consequences if a biological adaptation is possible.

In their histologic study comparing loaded vs. non-loaded implants, Gotfredsen et al. (200Ia) found that loaded implants presented with increased bone density and BIC. This information supports the hypothesis that the surrounding bone characteristics are in part a response to applied forces. Similar results were also reported in other orthodontically loaded implants (Roberts et al. I984; Wehrbein \& Diedrich I993; Wehrbein et al. I997). Yet, in the present study, BIC was not different among groups, suggesting that forces may have influenced this parameter similarly, despite the fact that wider implants have a greater total bone/implant area. Another potential explanation could be that transverse sections (Johansson \& Morberg I995a) or thinner histologic sections would discern minor differences (Johansson \& Morberg I995b), although small changes should have little impact in this study as comparison of groups is made with identical techniques.

It is also important to note that this study and others are focusing on normal physiologic forces. Excessive stress would likely result in other outcomes, including loss of marginal bone (Hoshaw et al. 1994) or loss of osseointegration (Isidor 1996). Excessive forces are clinically relevant to the prevention of implant or prosthetic failure. However, the study conditions presented in this report are different.

\section{Conclusion}

This animal study compared bone physiology in the vicinity of standard- and wide-diameter implants. Bone density in proximity to wide implants was decreased, when compared with narrower sizes, whereas all other parameters remained similar. This finding indicates that force distribution is more diluted when wider implants with a greater surface are placed. The clinical consequence may be in longterm maintenance of osseointegration, although long-term studies are needed to verify this hypothesis.

\section{Acknowledgements: The authors} would like to thank Dr Michael Rohrer and his team, at the University of
Minnesota, for their outstanding processing of histological samples. We are also grateful to Implant Innovations for providing customized implants and instrumentation. This research was supported by a grant at the University of Michigan.

\section{要旨}

目的：インプラントの骨性結合は骨質やイ ンプラント表面の性状など椂々な要因に依 存している。また骨代謝や咀嚼力の伝達の 変化に対する順応によっても影響される。 特に過剩な咬合圧はインプラントの喪失に つながるので、骨性結合の岥失を予防する 上で長期の生理的な調節を理解することは 不可欠である。この問題に対処するために、 インプラントの総表面積の増加は力学的抵 抗力の増加につながるであろうという望み に基づいて、直径の太いインプラントが導 入された。しかし直径の変化がインプラン 卜周辺の骨反応の変化につながるというエ ビデンスはほとんどない。従って本研究で はインプラントの直径が周辺の骨に及ぼす 影響を比較した。

材料と方法: 動物モデルを用いて標準径 $(3.75 \mathrm{~mm})$ のインプラント 20 本と直径 の太い $(5 \mathrm{~mm})$ インプラント 20 本を埋入 した。組織形態計測を行い、初期骨密度 (IBD)、骨-インプラントの接触率 (BIC) 及び隣接する骨の密度 (ABD) を測定した。 結果：標準径と太い径のインプラントにお いて BIC は各々 $71 \%$ と $73 \%$ ABD は $65 \%$ と $5 \%$ であった。これらの違いは 統計学的な有意差ではなかった $(\mathrm{p}>0$. 05 )。次に IBD との相関を調べた。BIC は IBD と相関していなかった。ABD は標 準径インプラントでは IBD と相関してい

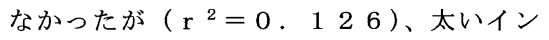
プラントでは相関していた $\left(\mathrm{r}^{2}=0.8\right.$ 2)。さらに太いインプラントでは IBD と $\mathrm{ABD}$ は 1 対 1 の比率になっていた。本研究 の制約内で、隣接する骨の密度はインプラ ントの直径により、おそらく力の伝達に差 異があるために、影響を受けている可能性 があると結論される。

\section{References}

Albrektsson, T., Dahl, E., Enbom, L., Engevall, S., Engquist, B., Eriksson, A.R., Feldmann, G., Freiberg, N., Glantz, P.O., Kjellman, O., Kirstersson, L., Kvint, S., Köndell, P., Palmquist, J., Werndahl, L. \& Ästrand, P. (I988) Osseointegrated oral implants. A Swedish multicenter study of 8I39 consecutively inserted Nobelpharma implants. Journal of Periodontology 59: 287-296.

Albrektsson, T. \& Sennerby, L. (I990) Direct bone anchorage of oral implants: clinical and experimental considerations of the concept of osseointegration. Parodontology I: 307-320.
Carr, A.B., Gerard, D.A. \& Larsen, P.E. (2000) Histomorphometric analysis of implant anchorage for 3 types of dental implants following 6 months of healing in baboon jaws. International Journal of Oral et) Maxillofacial Implants I 5: 785-79I.

Cho, P., Schneider, G.B., Krizan, K. \& Keller, J.C. (2004) Examination of the bone-implant interface in experimentally induced osteoporotic bone. Implant Dentistry I3: 79-87.

De Pauw, G.A., Dermaut, L.R., Johansson, C.B. \& Martens, G. (2002) A histomorphometric analysis of heavily loaded and non-loaded implants. Inter- national Journal of Oral « Maxillofacial Implants I7: 405-4I2.

Duyck, J., Ronold, H.J., Van Oosterwyck, H., Naert, I., Vander Sloten, J. \& Ellingsen, J.E. (200I) The influence of static and dynamic loading on marginal bone reactions around osseointegrated implants: an animal experimental study. Clinical Oral Implants Research I2: 207-2 I 8.

Goodacre, C.J., Bernal, G., Rung-Larassaerg, K. \& Kanjy, K. (2003) Clinical complications with implants and implant prostheses. Journal of Prosthetic Dentistry 90: I2 I-I32. 
Gotfredsen, K., Berglundh, T. \& Lindhe, J. (200Ia) Bone reactions adjacent to titanium implants subjected to static load of different duration. A study in the dog (III). Clinical Oral Implants Research I2: 552-558.

Gotfredsen, K., Berglundh, T. \& Lindhe, J. (200Ib) Bone reactions adjacent to titanium implants with different surface characteristics subjected to static load. A study in the dog (II). Clinical Oral Implants Research I2: 196-201.

Himmlova, L., Dostalova, T., Kacovsky, A. \& Konvickova, S. (2004) Influence of implant length and diameter on stress distribution: a finite element analysis. Journal of Prosthetic Dentistry 9I: 20-25.

Holmes, D.C. \& Loftus, J.T. (I997) Influence of bone quality on stress distribution for endosseous implants. Journal of Oral Implantology 23: IO4I I I.

Holmgren, E.P., Seckinger, R.J., Kilgren, L.M. \& Mante, F. (I998) Evaluating parameters of osseointegrated dental implants using finite element analysis- a two dimensional comparative study examining the effects of implant diameter, implant shape, and load direction. Journal of Oral Implantology 24: 80-88.

Hoshaw, S.J., Brunski, J.B. \& Cochran, G.V.B. (I994) Mechanical loading of Brånemark implants affects interfacial bone modeling and remodeling.
International Journal of Oral ↔) Maxillofacial Implants 9: 345-360.

Isidor, F. (I996) Loss of osseointegration caused by occlusal load of oral implants. A clinical and radiographic study in monkeys. Clinical Oral Implants Research 7: I43-I 52.

Ivanoff, C.J., Grondahl, K., Sennerby, L., Bergstrom, C. \& Lekholm, U. (I 999) Influence of variations in implant diameters: a 3 - to 5-year retrospective clinical report. International Journal of Oral 4 Maxillofacial Implants I4: I73-I 80.

Ivanoff, C.J., Sennerby, L., Johansson, C., Rangert, B. \& Lekholm, U. (I997) Influence of implant diameters on the integration of screw implants. An experimental study in rabbits. International Journal of Oral and Maxillofacial Surgery 26: I4I-I 48 .

Johansson, C.B. \& Albrektsson, T. (I987) Integration of screw implants in the rabbit: a I-year follow-up of removal torque of titanium implant. International Journal of Oral $\oplus$ Maxillofacial Implants 2: 69-75.

Johansson, C.B. \& Morberg, P. (I995a) Cutting directions of bone with biomaterials in situ does influence the outcome of histomorphometrical quantifications. Biomaterials I6: I037-1039.

Johansson, C.B. \& Morberg, P. (I995b) Importance of ground section thickness for reliable histomorphometrical results. Biomaterials I6: 9I-95.
Papavasiliou, G., Kamposiora, P., Bayne, S.C. \& Felton, D.A. (I996) Three-dimensional finite element analysis of stress-distribution around single tooth implants as a function of bony support, prosthesis type, and loading during function. Journal of Prosthetic Dentistry 76: 633-640.

Roberts, E.W., Smith, R.K., Zilberman, Y., Mozsary, P.G. \& Smith, R.S. (I984) Osseous adaptation to continuous loading of rigid endosseous implants. American Journal of Orthodontic 86: 95-III.

Rohrer, M.D. \& Schubert, C.C. (I992) The cuttinggrinding technique for histologic preparation of undecalcified bone and bone-anchored implants. Oral Surgery Oral Medicine Oral Pathology 74: 73-78.

Trisi, P., Lazzara, R., Rebaudi, A., Rao, W., Testori, T. \& Porter, S.S. (2003) Bone-implant contact on machined and dual acid-etched surfaces after 2 months of healing in the human maxilla. Journal of Periodontology 74: 945-956.

Wehrbein, H. \& Diedrich, P. (I993) Endosseous titanium implants during and after orthodontic load - an experimental study in the dog. Clinical Oral Implants Research 4: 76-82.

Wehrbein, H., Glatzmaier, J. \& Yildirim, M. (I997) Orthodontic anchorage capacity of short titanium screw implants in the maxilla. An experimental study in the dog. Clinical Oral Implants Research 8: I3I-I4I. 